\title{
PENGARUH DIVIDEN PAYOUT RATIO, FINANCIAL LEVERAGE DAN PROFITABILITAS TERHADAP BETA SAHAM
}

\section{(Studi Kasus Pada Perusahaan yang Terdaftar di Jakarta Islamic Index (JII) Tahun 2011-2013)}

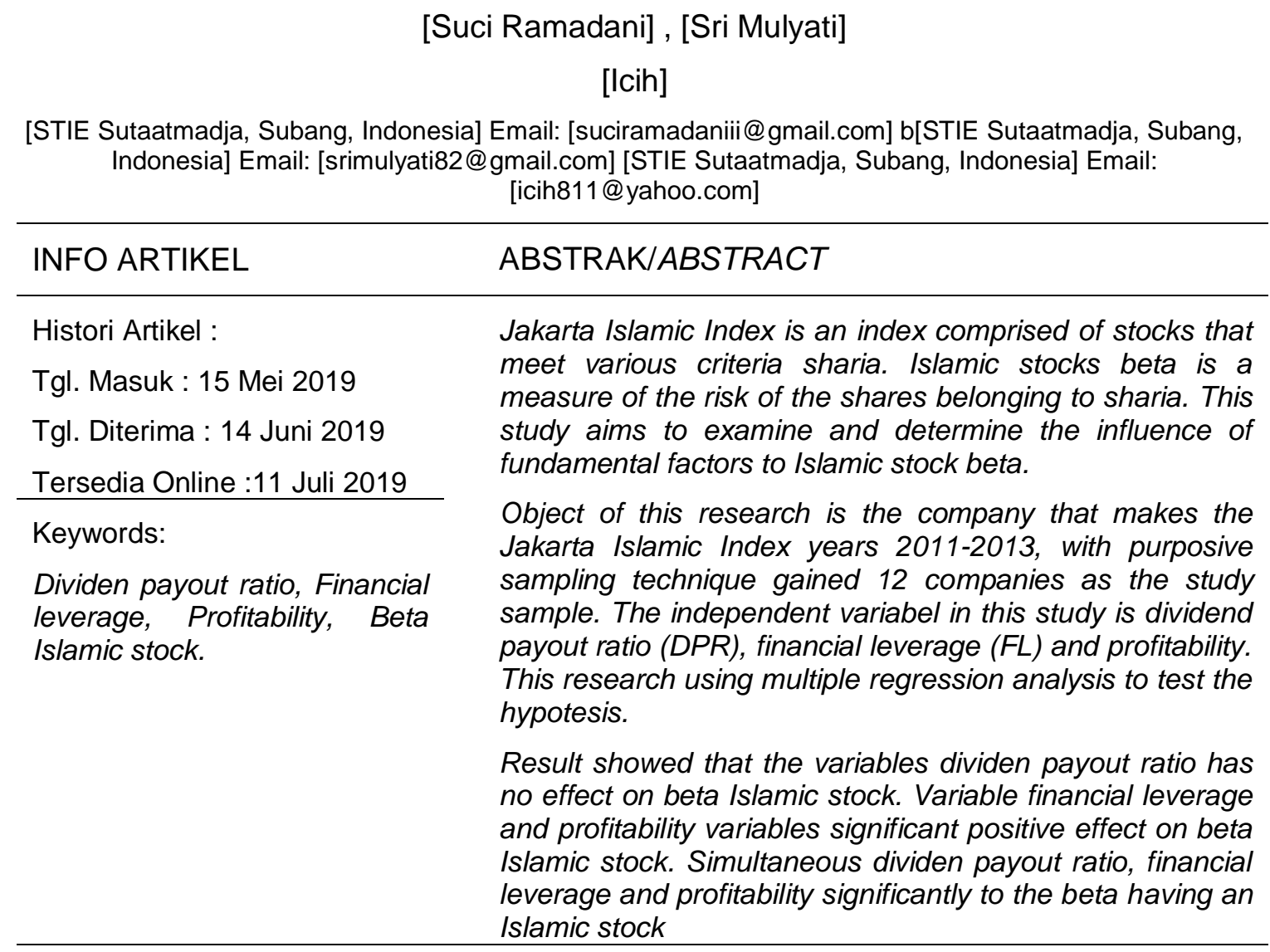

\section{PENDAHULUAN}

Perkembangan pasar modal di Indonesia telah memperlihatkan kemajuan seiring dengan perkembangan ekonomi Indonesia. Pasar modal mempunyai peran yang cukup strategis, yaitu sebagai sumber pendanaan, baik jangka pendek maupun jangka panjang bagi dunia usaha dan wahana investasi bagi investor. Seiring perkembangan pasar modal, maka dikembangkan pula pasar modal syariah yaitu pasar modal yang menggunakan prinsip, prosedur, asumsi, instrumentasi, dan aplikasi bersumber dari nilai Islam (Hamzah, 2005).

Pasar modal, baik pasar modal konvensional maupun pasar modal syariah memperdagangkan beberapa jenis sekuritas yang mempunyai tingkat risiko yang berbeda dan salah satunya adalah saham (Kustini \&Pratiwi, 2011). Menurut Hendy, Fakhrudin (2008 : 30) saham adalah surat berharga yang menunjukkan kepemilikan seorang investor di dalam suatu perusahaan yang artinya jika seseorang membeli saham suatu perusahaan, itu berarti dia telah menyertakan modal kedalam suatu perusahaan tersebut sebanyak jumlah saham yang dibeli.

Faktor yang secara teoritis dipertimbangkan dalam investasi saham adalah risiko. Risiko merupakan terjadinya penyimpangan atas keuntungan yang diharapkan. Menurut Hamzah (2005) 
terdapat 2 risiko dari sekuritas yaitu risiko sistematik dan risiko non sistematik. Risiko non sistematik dapat dihilangkan dengan membentuk portofolio yang baik. Sedangkan risiko sistematik tidak dapat dihilangkan dengan membentuk portofolio yang baik, dikarenakan risiko tersebut terjadi di luar perusahaan. Risiko sistematik dapat terjadi karena faktor ekonomi makro, industri, dan karakteristik perusahaan. Risiko sistematik juga disebut dengan beta, karena beta merupakan pengukur dari risiko sistematik. Beta suatu sekuritas merupakan hal yang penting untuk menganalisis sekuritas atau portofolio. Beta suatu sekuritas menunjukkan kepekaan tingkat keuntungan suatu sekuritas terhadap perubahan-perubahan pasar.

Beta saham $(\beta)$ merupakan pengukur risiko sistematis dari suatu saham atau portofolio relatif terhadap risiko pasar. Beta juga berfungsi sebagai pengukur volatilitas return saham, atau portofolio terhadap return pasar. Volatilitas merupakan fluktuasi return suatu saham atau portofolio dalam suatu periode tertentu, jika secara statistik fluktuasi tersebut mengikuti fluktuasi darireturn pasar, maka dikatakan beta dari sekuritas tersebut bernilai satu (Jogiyanto, 2007).

Pengukuran beta suatu saham dapat dilakukan dengan menggunakan Single Index Model (Husnan, 2001 : 46). Model ini berasumsi bahwa return saham berkorelasi dengan perubahan return pasar, dan untuk mengukur korelasi tersebut bisa dilakukan dengan menghubungkan return saham individual $\left(R_{i t}\right)$ dengan return indeks pasar $\left(R_{m t}\right)$.

Menurut Lestari (2013) dalam dunia investasi saham, ada satu fenomena mengenai kenaikan harga saham pada bulan Januari yang dikenal dengan istilah "January effect". Kenaikan tersebut diduga karena adanya peningkatan pembelian oleh para investor yang telah melakukan penjualan sahamnya pada Desember dalam rangka mengurangi pajak atau merealisasikan capital gain. Berdasarkan penelitian yang dilakukan selama periode 1989 sampai Maret 2009, diketahui bahwa bursa Indonesia pada bulan Januari juga mengalami return yang positif. Secara seasonal ditemukan bahwa Desember memberikan return paling tinggi dibandingkan bulan-bulan lain. Hal tersebut dapat diartikan bahwa investor di Indonesia telah mengantisipasi January effect yang telah menjadi fenomena bursabursa di dunia.

Investor mengantisipasi dengan mengakumulasikan saham-saham menjelang akhir tahun, sehingga terjadi peningkatan harga di bulan Desember. Hal ini disinyalir karena masih rendahnya pajak untuk berinvestasi di pasar saham Indonesia, sehingga investor tidak menjual sahamnya menjelang akhir tahun, bahkan meningkatkan portofolionya untuk mengantisipasi fenomena January effect yang terjadi di bursa dunia. Jadi, dapat dikatakan bahwa yang terjadi di bursa Indonesia bukan January effect melainkan Desember effect.

Inilah dasar peneliti untuk
mengetahui faktor-faktor yang mempengaruhi beta saham. Terdapat banyak faktor-faktor yang mempengaruhi beta saham. Dalam penelitian ini faktorfaktor yang akan diteliti adalah deviden payout ratio, financial leveragedan profitabilitas. Beta saham dipilih karena investasi saham syariah menurut Aruzzi \& Bandi (2003) dalam Kustini (2011) akan memberikan return yang lebih baik dibandingkan dengan investasi saham biasa. Investasi saham syariah berdasarkan prinsip bagi hasil, mengandung ketidakpastian return yang tinggi. Selain itu juga, alasan peneliti menggunakan perusahaan yang terdaftar di JII karena berdasarkan data yang ada, pertumbuhan indeks JII lebih besar dibandingkan dengan Indeks Harga Saham Gabungan. Pertumbuhan Indeks untuk JII adalah sebesar $17 \%$ sedangkan Indeks Harga Saham Gabungan (IHSG) tumbuh sebesar $13 \%$ pada tahun 2012 (m.beritametro.co.id).

Dalam paragraf sebelumnya telah disebutkan bahwa penelitian ini akan membahas faktor-faktor yang mempengaruhi beta saham. Faktor 
pertama adalah Dividen payout ratio. Menurut Indriyo \& Basri (2002) Deviden payout ratio adalah perbandingan antara deviden yang dibagi dengan laba bersih yang diperoleh, biasanya dalam bentuk presentase. Return dan risiko mempunyai hubungan yang positif (Jogiyanto, 2003 :130), karena beta merupakan pengukur risiko maka dapat dikatakan bahwa beta dan dividen payout ratio mempunyai hubungan. Peningkatan dividen payout ratio akan mendorong kenaikan risiko saham

Faktor kedua adalah financial leverage. Menurut Suad (1998, 611) financial leverage terjadi pada saat perusahaan menggunakan hutang dan menimbulkan beban tetap (bunga) harus dibayar dari hasil operasi. Semakin besar proporsi hutang yang dipergunakan, semakin besar financial leverage-nya, hal ini mengakibatkan perusahaan harus menanggung biaya bunga yang besar pula. Tentunya ini akan mengurangi laba perusahaan. Semakin kecil laba perusahaan maka semakin kecil tingkat risiko perusahaan, karena return dan risiko mempunyai hubungan yang positif.

Faktor ketiga yang mempengaruhi beta saham adalah profitabilitas. Menurut Syafri (2008) rasio profitabilitas adalah rasio yang menggambarkan kemampuan perusahaan didalam mendapat laba melalui semua kemampuan dan juga sumber yang ada seperti kegiatan penjualan, kas, modal, jumlah karyawan, jumlah cabang dan lain-lain. Keuntungan yang dicapai perusahaan memberikan nilai positif bagi perusahaan, dan akan meningkatkan beta atau risiko perusahaan, karena keuntungan atau return menurut (Jogiyanto, 2003:130) meempunyai hubungan yang positif dengan risiko. Dengan demikian berdasarkan latar belakang di atas yang akan diteliti oleh peneliti "PENGARUH DIVIDEN PAYOUT RATIO, FINANCIAL LEVERAGE DAN PROFITABILITAS TERHADAP BETA SAHAM".

Tujuan penelitian ini adalah untuk mengetahui apakah variabel independen (dividen payout ratio, financial leverage dan profitabilitas) memiliki pengaruh signifikan terhadap variabel dependen (beta saham) pada perusahaan yang terdaftar di Jakarta Islamic Index (JII) dalam kurun waktu 2011-2013, baik secara parsial maupun secara simultan.

\section{KERANGKA TEORITIS DAN PENGEMBANGAN HIPOTESIS}

\section{Akuntansi Syariah}

APB (Accounting Principle Board) Statement No.4 dalam Muhammad (2005 : 10) mendefinisikan akuntansi sebagai berikut :

Akuntansi adalah suatu kegiatan jasa. Fungsinya adalah memberikan informasi kuantitatif, umumnya dalam ukuran uang, mengenai suatu badan ekonomi yang dimaksudkan untuk digunakan dalam pengambilan keputusan ekonomi, yang digunakan dalam memilih diantara beberapa alternatif.

Secara etimologi, kata Syari'ah berasal dari bahasa Arab, dari kata Syara'a yang berarti jalan. Syari'ah Islam berarti jalan dalam agama Islam atau peraturan dalam Islam. Sedangkan secara terminologi Syari'ah adalah suatu sistem norma illahi yang mengatur hubungan manusia dengan Tuhannya, hubungan manusia dengan sesamanya dan hubungan manusia dengan seluruh ciptaan Tuhan di alam semesta (Muhammad, 2005).

Dari definisi-definisi tersebut dapat disimpulkan bahwa Akuntansi Syari'ah adalah aktifitas yang teratur berkaitan dengan pencatatan transaksi-transaksi, tindakan-tindakan, keputusan-keputusan yang sesuai dengan syari'at dan ketentuan Islam, untuk membantu pengambilan keputusan yang tepat.

\section{Jakarta Islamic Index (JII)}

Indeks syari'ah merupakan indeks berdasarkan syari'ah Islam. Berdasarkan arahan Dewan Syari'ah Nasional dan Peraturan Bapepam-LK Nomor IX.A.13 tentang Penerbitan Efek Syari'ah, jenis kegiatan utama suatu badan usaha yang tidak memenuhi syari'ah adalah : 
1. Usaha perjudian dan permainan yang tergolong judi atau perdagangan yang dilarang

2. Menyelenggarakan jasa keuangan yang menerapkan konsep ribawi, jual beli risiko yang mengandung gharar dan maysir.

3. Memproduksi, mendistribusikan, memperdagangkan dan atau menyediakan :

a. Barang dan atau jasa yang haram karena zatnya (haram li-dzatihi)

b. Barang dan atau jasa yang haram bukan karena zatnya (haram lighairihi) yang ditetapkan oleh DSNMUI, dan atau

c. Batang dan atau jasa yang merusak moral dan bersifat mudharat.

Sedangkan kriteria saham yang masuk dalam kategori syari'ah adalah sebagai berikut :

1. Tidak melakukan kegiatan usahan sebagaimana yang diuraikan di atas.

2. Tidak melakukan perdagangan yang tidak disertai dengan penyerahan barang/jasa dan perdagangan dengan penawaran dan permintaan palsu.

3. Tidak melebihi rasio keuangan sebagai berikut :

a. Total hutang yang berbasis bunga dibandingkan dengan total ekuitas tidak lebih dari $82 \%$ (hutang yang berbasis bunga dibandingkan dengan total ekuitas tidak lebih dari $45 \%: 55 \%$ )

b. Total pendapatan bunga dan pendapatan tidak halal lainnya dibandingkan dengan total pendapatan (revenue) tidak lebih dari $10 \%$.

Menurut Heri (2007: 194-195) Jakarta islamic index (JII) merupakan indeks yang dikembangkan oleh Bursa Efek Jakarta (BEJ) bekerja sama dengan Danareksa Investment Management.

Jakarta islamic index terdiri dari 30 perusahaan yang dipilih dari sahamsaham yang sesuai dengan syari'ah Islam. Pada awal peluncurannya, pemilihan saham yang masuk dalam kriteria syari'ah melibatkan pihak Dewan Pengawas
Syari'ah PT Danareksa Investment Management. Akan tetapi seiring perkembangan pasar, tugas pemilihan saham-saham tersebut dilakukan oleh Bapepam-LK, bekerja sama dengan Dewan Syari'ah Nasional. Hal ini tertuang dalam Peraturan Bapepam-LK Nomor II.K.1 tentang Kriteria dan Penerbitan daftar Efek Syari'ah (www.sahamok.com).

Untuk menetapkan saham-saham yang masuk dalam perhitungan Jakarta islamic index dilakukan proses seleksi sebagai berikut :

1. Saham-saham yang akan dipilih berdasarkan Daftar Efek Syari'ah (DES) yang dikeluarkan oleh BapepamLK.

2. Memilih 60 saham dari Daftar Efek Syari'ah tersebut berdasarkan urutan kapitalisasi pasar terbesar selama 1 tahun terakhir.

3. Dari 60 saham tersebut, dipilih 30 saham berdasarkan tingkat likuiditas yaitu nilai transaksi di pasar reguler selama 1 tahun terakhir.

\section{Beta Saham}

Menurut Jogiyanto (2003): "Beta merupakan suatu volatilitas dari return suatu sekuritas atau return portofolio terhadap return pasar. Beta sekuritas ke-i mengukur volatilitas return portofolio dengan return pasar." Berdasarkan pendapat tersebut dapat dipahami bahwa beta merupakan pengukur risiko sistematik dari suatu sekuritas atau portofolio relatif terhadap risiko pasar.

Suad (2005:112) terdapat beberapa faktor yang diidentifikasi mempengaruhi risiko sistematik (beta). Faktor-faktor tersebut adalah sebagai berikut :

\section{Cyclicality \\ 2. Operating Leverage \\ 3. Financial leverage}

Menurut Husnan (2001) penilaian terhadap beta ada tiga kondisi yaitu :

1. Apabila $\beta=1$, berarti tingkat keuntungan saham i berubah secara proporsional dengan tingkat keuntungan pasar. Ini menandakan 
bahwa risiko sistematis saham i sama dengan risiko sistematis pasar.

2. Apabila $\beta>1$, berarti tingkat keuntungan saham i lebih besar dibanding dengan tingkat keuntungan keseluruhan saham i di pasar. Ini menandakan bahwa risiko sistematis saham i lebih besar dibandingkan dengan risiko sistematis pasar, atau sering disebut saham agresif.

3. Apabila $\beta<1$, berarti tingkat keuntungan saham i meningkat lebih kecil dibanding dengan tingkat keuntungan keseluruhan saham di pasar. Ini menandakan bahwa risiko sistematis saham i lebih kecil dibandingkan dengan risiko sistematis pasar, sering disebut saham defensif.

Menurut Jogiyanto (2010:379) beta dapat dihitung dengan menggunakan teknik regresi. Teknik regresi untuk mengestimasikan beta suatu sekuritas dapat dilakukan dengan menggunakan return-return pasar sebagai variabel independen. Beta dapat dihitung dengan berdasarkan persamaan regresi sebagai berikut :

$$
R_{i t}=\alpha i+\beta i R_{m t}+e_{i t}
$$

Mengetahui beta saham syari'ah merupakan hal yang penting unuk menganalisa sekuritas tersebut. Beta suatu sekuritas menunjukkan risiko sistematis dari sekuritas tersebut yang tidak dapat dihilangkan dengan diversifikasi (Lukas Setia Atmaja 2008:45).

\section{Dividen Payout Ratio}

Menurut Indriyo \& Basri (2002) dalam Kustini (2011) Dividen payout ratio adalah perbandingan antara dividen yang dibagikan dengan laba bersih yang diperoleh, biasanya dalam bentuk presentase. Semakin tinggi dividen payout ratio akan menguntungkan para investor tapi dari pihak perusahaan akan memperlemah internal finansial karena memperkecil laba ditahan. Tetapi sebaliknya dividen payout ratio semakin kecil akan merugikan investor tetapi internal finansial perusahaan semakin kuat.

Menurut Bambang Riyanto (2001), ada beberapa cara menetapkan dividen payout ratio, yaitu :

1. Kebijakan dividen yang stabil

2. Kebijakan dividen dengan penetapan jumlah dividen minimal plus ekstra tertentu

3. Kebijakan dividen dengan penetapan dividen payout ratio yang konstan

4. Kebijakan dividen yang fleksibel

Dari uraian di atas, rumus yang digunakan oleh peneliti untuk mengukur dividen payout ratio sebagai berikut :

$$
\text { DPR }=\frac{\text { Deviden Per Share }}{\text { Earning Per Share }}
$$

\section{Financial Leverage}

Menurut Suad (2005) arti harfiah kata leverage adalah kekuatan pengungkit, yaitu dari kata dasar lever yang berarti pengungkit. Ada dua tipe leverage, yaitu operating leverage dan financial leverage. Operating leverage terjadi pada saat perusahaan menggunakan aktiva yang menimbulkan beban tetap yang harus ditutup dari hasil operasinya. Financial leverage terjadi pada saat perusahaan menggunakan hutang dan menimbulkan beban tetap (bunga) yang harus dibayar dari hasil operasi. Apabila perusahaan menggunakan hutang, maka perusahaan harus membayar bunga. Bunga ini harus dibayar, berapapun keuntungan operasi perusahaan.

Menurut Sawir (2000:13) ada dua jenis rasio leverage, yaitu:

1. Rasio Utang terhadap Aktiva atau Debt to Total Asset Ratio

Rasio ini memperlihatkan proporsi antara kewajiban yang dimiliki dan seluruh kekayaan yang dimiliki. Semakin tinggi hasil presentasenya cenderung semakin besar risiko 
keuangannya bagi kreditor maupun pemegang saham.

$$
\text { DER }=\frac{\text { Total Hutang }}{\text { Ekuitas }} \times 100 \%
$$

2. Rasio Utang terhadap Modal atau Debt to Equity Ratio

Rasio ini menggambarkan perbandingan utang dan ekuitas dalam pendanaan perusahaan dan menunjukkan kemampuan modal sendiri perusahaan tersebut untuk memenuhi seluruh kewajibannya.

$$
\text { DAR }=\frac{\text { Total Hutang }}{\text { Total Aktiva }} \times 100 \%
$$

Dalam penelitian ini jenis rasio leverage yang digunakan oleh peneliti adalah Debt to Total Asset Ratio karena penelitian terdahulu banyak menggunakan Debt to Equity Ratio.

\section{Profitabilitas}

Menurut Sartono (2010:122) yang menyatakan bahwa profitabilitas adalah kemampuan perusahaan memperoleh laba dalam hubungannya dengan penjualan, total aktiva maupun modal sendiri. Menurut Kasmir (2011:196) menyatakan bahwa rasio profitabilitas merupakan rasio untuk menilai kemampuan perusahaan dalam mencari keuntungan.

Irawati (2006 : 58) dalam rasio keuntungan ada beberapa rumusan yang digunakan diantaranya adalah :
1. Gross Profit Margin
2. Operating Profit Margin
3. Operating Ratio
4. Net Profit Margin
5. Return on Assets
6. Return on Equity
7. Return on Investment
8. Earning Per Share

Dalam penelitian ini rasio yang digunakan untuk mengukur profitabilitas adalah return on assets (ROA) karena penelitian sebelumnya lebih banyak menggunakan return on investment dan return on equity.

\section{Return on Assets}

Pengertian return on assets (ROA) menurut Irawati (2006:59) yang menyatakan bahwa :

Return On Assets (ROA) adalah kemampuan suatu perusahaan (aktiva perusahaan) dengaan seluruh modal yang bekerja di dalamnya untuk menghasilkan laba operasi perusahaan (EBIT) atau perbandingan laba usaha dengan modal sendiri dan modal asing yang digunakan untuk menghasilkan laba dan dinyatakan dalam presentase.

Hanafi \& Halim (2009) rasio ini mengukur kemampuan perusahaan dalam menghasilkan laba dengan menggunakan total aset (kekayaan) yang dimiliki perusahaan setelah disesuaikan dengan biaya-biaya untuk mendanai aset tersebut. Biaya-biaya pendanaan yang dimaksud adalah bunga yang merupakan biaya pendanaan dengan hutang. Perhitungannya adalah sebagai berikut :

$$
\text { ROA }=\frac{\text { Laba Bersih Sebelum Pajak }}{\text { Total Asset }} \times 100 \%
$$

\section{Hipotesis}

\section{Pengaruh Dividen Payout Ratio Terhadap Beta Saham}

Jogiyanto (2008) dividen payout ratio adalah dividen yang dibayarkan dibagi dengan laba yang tersedia untuk pemegang saham umum. Return dan risiko mempunyai hubungan yang positif (Jogiyanto, 2003:130) Karena beta merupakan pengukur risiko maka dapat juga dikatakan bahwa beta dan dividen payout ratio mempunyai hubungan. Peningkatan dividen payout ratio akan mendorong kenaikan risiko saham.

Hasil penelitian yang dilakukan oleh Sri Kustini \& Selvi Pratiwi (2011) mengambil kesimpulan bahwa variabel dividen payout ratio mempunyai pengaruh negatif signifikan terhadap beta saham syariah. 
Dari uraian diatas dapat disimpulkan hipotesis 1 yang dikemukakan dalam penelitian ini adalah :

\section{H1 : Dividen Payout Ratio Berpengaruh Terhadap Risiko Sistematik (Beta Saham).}

\section{Pengaruh Financial Leverage Terhadap Beta Saham}

Sartono (2008: 120) menyatakan bahwa financial leverage menunjukkan proporsi penggunaan hutang untuk membiayai investasi perusahaan. Perusahaan yang tidak mempunyai leverage berarti menggunakan modal sendiri $100 \%$.

Semakin tinggi nilai financial leverage menunjukkan perusahaan menanggung hutang yang semakin besar. Hal ini mengakibatkan perusahaan harus menanggung biaya bunga yang lebih besar pula. Tentunya ini akan mengurangi laba perusahaan, semakin kecil laba perusahaan maka semakin kecil tingkat risiko perusahaan, karena keduanya mempunyai hubungan yang positif menurut (Jogiyanto, 2003:130).

Teori ini sejalan dengan penelitian yang dilakukan Ni'mah (2013) menunjukkan bahwa financial leverage berpengaruh negatif signifikan terhadap risiko investasi (beta).

Dari uraian diatas dapat disimpulkan hipotesis 2 yang dikemukakan dalam penelitian ini adalah :

\section{H2 : Financial Leverage \\ Berpengaruh Negatif Terhadap Risiko Sistematik (Beta Saham)}

\section{Pengaruh Profitabilitas Terhadap Beta Saham}

Hanafi \& Halim (2009) return on assets adalah rasio yang mengukur kemampuan perusahaan dalam menghasilkan laba dengan menggunakan total aset (kekayaan) yang dimiliki perusahaan setelah disesuaikan dengan biaya-biaya untuk mendanai aset tersebut. Biaya-biaya pendanaan yang dimaksud adalah bunga yang merupkan biaya pendanaan dengan hutang.
Keuntungan yang dicapai perusahaan memberikan nilai positif bagi perusahaan, dan akan meningkatkan risiko, karena risiko dan keuntungan atau return mempunyai hubungan yang positif (Jogiyanto, 2003:130). Sehingga dapat ditarik kesimpulan bahwa return on assets berpengaruh terhadap beta saham syari'ah.

Dari uraian diatas dapat disimpulkan hipotesis 3 yang dikemukakan dalam penelitian ini adalah :

\section{H3 : Return On Asset Berpengaruh Terhadap Risiko Sistematik (Beta Saham)}

\section{METODOLOGI PENELITIAN}

\section{Jenis, Sumber Data dan Teknik Pengumpulan Data}

Jenis data yang digunakan oleh peneliti merupakan data sekunder. Sumber data yang digunakan dalam penelitian ini adalah berupa laporan keuangan tahunan perusahaan yang terdaftar di Jakarta Islamic Index (JII). Data yang diperoleh dalam penelitian ini bersumber dari pengaksesan internet melalui www.idx.co.id.

Untuk memperoleh data yang diperlukan dalam penelitian ini, teknik pengumpulan data yang digunakan adalah studi dokumentasi dan studi kepustakaan.

\section{Populasi dan Sampel}

$$
\text { Populasi adalah wilayah }
$$
generalisasi yang terdiri atas: obyek/subyek yang mempunyai kualitas dan karakteristik tertentu yang ditetapkan oleh peneliti unutuk dipelajari dan kemudian ditarik kesimpulannya. Jadi populasi bukan hanya orang, tetapi juga obyek dan benda-benda alam yang lain. Populasi juga bukan sekedar jumlah yang ada pada obyek/subyek yang dipelajari, tetapi meliputi seluruh karakteristik/sifat yang dimiliki oleh subyek atau obyek itu (Sugiyono, 2014:80). Populasi dari penelitian ini adalah perusahaan yang terdaftar di Jakarta islamic index. 
Berdasarkan penjelasan diatas, untuk membuktikan kebenaran jawaban yang masih sementara (hipotesis), maka penulis melakukan pengumpulan data pada objek tertentu. Karena objek dalam populasi terlalu luas, maka peneliti menggunakan sampel yang diambil dari populasi tersebut.

\section{Teknik Pemilihan Sampel}

Teknik pemilihan sampel yang diterapkan dalam penelitian ini adalah non probability sampling, Sedangkan metode sampel yang dipilih adalah purposive sampling. Purposive sampling adalah teknik penentuan sampel dengan pertimbangan tertentu (Sugiyonoo, 2014:85). Kriteria-kriteria yang harus dipenuhi untuk dijadikan sampel dalam penelitian ini adalah sebagai berikut:

1. Perusahaan yang konsisten terdaftar di Jakarta islamic index dan tercatat (listed) di Bursa Efek Indonesia (BEI) selama kurun waktu 2011-2013.

2. Perusahaan yang mempublikasikan laporan tahunan (annual report) pada tahun 2011-2013 karena memudahkan dalam menghitung variabel yang diteliti.

3. Perusahaan yang memiliki data lengkap mengenai variabel yang diteliti selama tahun 2011-2013.

\section{Variabel Independen (X)}

Variabel independen dalam penelitian ini adalah dividen payout ratio, financial leverage dan profitabilitas.

\section{Dividen Payout Ratio $\left(X_{1}\right)$}

Indriyo \& Basri (2002) dalam Kustini (2011) Dividen payout ratio adalah perbandingan antara dividen yang dibagikan dengan laba bersih yang diperoleh, biasanya dalam bentuk presentase. Skala yang dugunakan adalah rasio. Dalam penelitian ini, dividen payout ratio dihitung menggunakan rumus:

$$
\text { DPR }=\frac{\text { Deviden Per Share }}{\text { Earning Per Share }}
$$

\section{Financial Leverage $\left(X_{2}\right)$}

Menurut Suad (2005) arti harfiah kata leverage adalah kekuatan pengungkit, yaitu dari kata dasar lever yang berarti pengungkit. Ada dua tipe leverage, yaitu operating leverage dan financial leverage. Operating leverage terjadi pada saat perusahaan menggunakan aktiva yang menimbulkan beban tetap yang harus ditutup dari hasil operasinya. Financial leverage terjadi pada saat perusahaan menggunakan hutang dan menimbulkan beban tetap (bunga) yang harus dibayar dari hasil operasi. Apabila perusahaan menggunakan hutang, maka perusahaan harus membayar bunga. Bunga ini harus dibayar, berapapun keuntungan operasi perusahaan. Menurut Sawir (2000:13) ada dua jenis rasio financial leverage, yaitu rasio utang terhadap aktiva atau Debt to Total Asset Ratio dan rasio utang terhadap modal atau Debt to Equity Ratio. Dalam penelitian ini rasio yang digunakan adalah rasio utang terhadap aktiva atau Debt to Total Asset Ratio Skala yang digunakan adalah rasio. Rumus yang digunakan adalah:

$$
\text { DAR }=\frac{\text { Total Hutang }}{\text { Total Aktiva }} \times 100 \%
$$

3. Profitabilitas $\left(\mathrm{X}_{3}\right)$

Profitabilitas adalah kemampuan perusahaan memperoleh laba dalam hubungannya dengan penjualan, total aktiva maupun modal sendiri (Sartono 2010:122) dalam penelitian ini rasio profitabilitas yang digunakan adalah Return on Asset. Skala yang digunakan adalah rasio. Return on Asset dapat dihitung dengan rumus:

ROA $=\frac{\text { Laba Bersih Sebelum Pajak }}{\text { Total Asset }} \times 100 \%$

\section{Variabel Dependen (Y)}

Variabel dependen yang digunakan dalam penelitian ini adalah beta saham. Beta merupakan volatilitas dari return suatu sekuritas atau return portofolio terhadap return pasar. Berdasarkan pendapat tersebut dapat dipahami bahwa 
beta merupakan pengukur risiko sistematik dari suatu sekuritas atau portofolio relatif terhadap risiko pasar (Jogiyanto, 2003)

Menurut Jogiyanto (2010:397) beta dapat dihitung dengan menggunakan teknik regresi. Teknik regresi ini untuk mengestimasikan beta suatu sekuritas dapat dilakukan dengan menggunakan return-return pasar sebagai variabel independen. Beta dapat dihitung dengan berdasarkan persamaan regresi sebagai berikut :

$$
R_{i t}=\alpha i+\beta i R_{m t}+e_{i t}
$$

\section{Metode Analisis Data}

\section{Analisis Statistik Deskriptif}

Stastistik deskriptif adalah statistik yang digunakan untuk menganalisis data dengan cara mendeskripsikan atau menggambarkan data yang telah terkumpul sebagaimana adanya tanpa bermaksud membuat kesimpulan yang berlaku untuk umum atau generalisasi (Sugiyono, 2014:147).

\section{Uji Asumsi Klasik}

Untuk menghasilkan suatu model yang baik, maka analisis regresi memrlukan pengujian asumsi klasik sebelum melakukan pengujian hipotesis, pengajuan asumsi klasik tersebut melalui :

\section{Uji Normalitas}

Uji normalitas bertujuan untuk menguji apakah dalam model regresi, variabel pengganggu atau residual memiliki distribusi normal. Seperti diketahui bahwa uji $t$ dan $F$ mengasumsikan bahwa nilai residual mengikuti distribusi normal. Kalau asumsi ini dilanggar maka uji statistik menjadi tidak valid untuk jumlah sampel kecil. Ada dua cara untuk mendeteksi apakah residual berdistribusi normal atau tidak yaitu dengan analisis grafik dan uji statistik (Ghozali, 2013 : 160). Terdapat dua cara untuk mengetahui apakah residual distribusi normal atau tidak yaitu dengan analisis grafik dan uji statistik. Uji ini dilakukan sebelum data diolah. Pendeteksian normalitas data apakah terdistribusi normal atau tidak dengan menggunakan uji Kolmogorov-Smirnov dan plot normal / observed cum prob. Residual dinyatakan terdistribusi normal jika nilai signifikansi Kolmograv-Smirnov > 0,05 .

\section{Uji Multikoliniearitas}

Uji multikoliniearitas betujuan untuk menguji apakah model regresi ditemukan adanya korelasi antar variabel bebas (independen). Model regresi yang baik seharusnya tidak terjadi korelasi diantara variabel independen. Kriterian untuk menilai terdapat atau tidaknya masalah multikoliniearitas adalah:

a. Jika nilai $\mathrm{VIF}<10$ dan nilai tolerance $>$ 0,1 , hal tersebut menunjukan bahwa tidak terdapat masalah multikoliniearitas

b. Jika nilai VIF $>10$ dan nilai tolerance< 0,1 , hal tersebut menunjukan bahwa terdapat masalah multikoliniearitas

\section{Uji Heteroskedastisitas}

Uji heteroskedastisitas bertujuan menguji apakah dalam model regresi terjadi ketidaksamaan varian dari residual satu pengamatan kepengamatan yang lain. Jika variance dari residual satu pengamatan kepengamatan lain tetap, maka disebut homoskedastisitas, dan jika berbeda disebut heterokedastisitas. Model regresi yang baik adalah yang homokedastisitas atau tidak terjadi heterokedastisitas (Gozali, 2013:139).

Pengujian heteroskedastisitas dalam penelitian ini menggunakan grafik plot, deteksi ada tidaknya heteroskedastisitas dapat dilakukan dengan melihat ada tidaknya pola tertentu pada grafik scatteplot antara SRESID dan ZPRED dimana sumbu $Y$ adalah $Y$ yang telah diprediksi dan sumbu $X$ adalah residual ( $Y$ prediksi- $Y$ sesungguhnya) yang telah di-studentized (Ghozali, 2013:139).

4. Uji Autokorelasi

Menurut Ghozali (2013,110), Uji autokorelasi dilakukan untuk menguji apakah dalam model regresi linier ada 
korelasi antara kesalahan penggangu pada priode $t$ dengan kesalahan penggangu pada priode t-1 (sebelumnya), dalam suatu hubungan analisis regresi dimungkinkan terjadinya hubungan antara variabel - variabel independent itu sendiri. Untuk menditeksi gejala terjadinya autokorelasi menurut Revolitasari (2010), dapat digunakan dengan pengujian Durbin-watson.

\section{Analisis Regresi Berganda}

Analisis data dalam penelitian ini menggunakan regresi berganda. Dalam penelitian ini terdapat tiga variabel independen yaitu dividen payout ratio, financial leverage dan profitabilitas, serta satu variabel dependen yaitu beta saham yang mempunyai hubungan yang saling mempengaruhi antara keempat variabel tersebut.

Persamaan umum regresi berganda yang digunakan dalam penelitian ini yaitu :

Keterangan :

$\mathrm{Y}=$ Variabel dependen (Beta Saham Syariah)

$\mathrm{X}_{1}=$ Variabel independen (Dividen payout ratio)

$\mathrm{X}_{2}=$ Variabel bebas (Financial leverage)

$\mathrm{X}_{3}=$ Variabel bebas (Profitabilitas)

a $=$ Konstanta/ intersep

$\mathrm{b}_{\mathrm{i}}=$ Koefisien regresi/ slope (kemiringan garis)

$\mathrm{e}=$ Error

\section{Pengujian Hipotesis}

Hipotesis yang digunakan dalam penelitian ini untuk melihat ada tidaknya pengaruh variabel independen. Hipotesis nol (Ho) menunjukan tidak adanya pengaruh antara variabel independen dan variabel dependen, Hipotesis penelitian (Ha) menunjukan adanya pengaruh antara variabel independen dan variabel dependen.

\section{Uji Signifikansi Parameter Individual (Uji Statistik t)}

Uji statistik $t$ pada dasarnya menunjukan seberapa jauh pengaruh satu variabel penjelas/independen secara induvidual dalam menerangkan variasi variabel dependen (Ghozali, 2013:98).

Pengujian terhadap hipotesis dilakukan dengan menggunakan $\alpha=5 \%$. Kaidah dalam pengambilan keputusan adalah :

a. Jika nilai probabilitas (sig.) $<\alpha=5 \%$ maka hipotesis alternative diterima.

b. Jika nilai probabilitas (sig.) $>\alpha=5 \%$ maka hipotesis alternative tidak dapat diterima.

\section{Uji Signifikan Simultan (Uji Statistik F)}

Uji $F$ digunakan untuk menguji signifikan koefisien regresi secara keseluruhan dan pengaruh variabel bebas secara bersama - sama (Khusumadilaga,

$$
Y=a+b_{1} X_{1}+b_{2} X_{2}+b_{3} X_{3}+e
$$

2010).

Pengujian terhadap hipotesis dilakukan dengan menggunakan $\alpha=5 \%$. Kaidah dalam pengambilan keputusan adalah :

a. Jika nilai probabilitas (sig.) $<\alpha=5 \%$ maka hipotesis alternative diterima.

b. Jika nilai probabilitas (sig.) $>\alpha=5 \%$ maka hipotesis alternative tidak dapat diterima.

\section{Koefisien Determinasi $\left(\mathbf{R}^{2}\right)$}

Koefesien determinasi $\left(R^{2}\right)$ pada intinya mengukur seberapa jauh kemampuan model dalam menerangkan variasi variabel dependen. Nilai koefesien determinasi adalah antara nol sampai dengan satu. Nilai $R^{2}$ yang kecil berarti kemampuan variabel-variabel independen dalam menjelaskan variasi variabel dependen amat terbatas. Nilai yang mendekati satu berarti variabel-variabel 
independen memberikan hampir semua informasi yang dibutuhkan untuk untuk memprediksi variasi variabel dependen (Ghozali, 2013).

\section{HASIL DAN PEMBAHASAN}

\section{Uji Statistik Deskriptif}

\section{Tabel 1 \\ Uji Statistik Deskriptif}

\section{Descriptive Statistics}

\begin{tabular}{|l|r|r|r|r|r|}
\hline & $\mathrm{N}$ & Minimum & Maximum & Mean & $\begin{array}{c}\text { Std. } \\
\text { Deviation }\end{array}$ \\
\hline $\mathrm{B}$ & 36 & -.2043 & 2.2879 & .963528 & .7306825 \\
DPR & 36 & .2500 & 1.0060 & .5201 & .2210156 \\
FL & 36 & .13 & 1.21 & .3644 & .20381 \\
ROA & 36 & .039 & .431 & .1908 & .0971695 \\
Valid N (listwise) & 36 & & & & \\
\hline
\end{tabular}

Sumber: Output SPSS 2015

Berdasarkan tabel 4.6 menunjukan bahwa jumlah keseluruhan sampel yang diteliti dalam pengujian ini yaitu sebanyak 36 sampel, dengan empat variabel penelitian, yaitu:

1. Berdasarkan tabel 4.6 hasil statistik deskriptif terhadap $\beta$ pada penelitian ini menunjukan nilai maximum sebesar 2,2879 , nilai minimum sebesar $-0,2043$, nilai mean sebesar 0,963528 dan nilai standar deviation 0,7306825.

2. Berdasarkan tabel 4.6 hasil statistik deskriptif terhadap DPR pada penelitian ini menunjukan nilai maximum sebesar 1,0060, nilai minimum sebesar 0,2500 , nilai mean sebesar 0,5201, dan nilai standar deviation 0,2210156.

3. Berdasarkan tabel 4.6 hasil statistik deskriptif terhadap FL pada penelitian ini menunjukan nilai maximum sebesar 1,21 , nilai minimum sebesar 0,13 , nilai mean sebesar 0,3644 , dan nilai standar deviation 0,20381.

4. Berdasarkan tabel 4.6 hasil statistik deskriptif terhadap ROA pada penelitian ini menunjukan nilai maximum sebesar 0,431 , nilai minimum sebesar 0,039 , nilai mean sebesar 0,1908 , dan nilai standar deviation 0,0971695.Pengujian Hipotesis

\section{Uji Asumsi Klasik}

Untuk menghasilkan suatu model yang baik, maka analisis regresi memerlukan pengujian asumsi klasik sebelum melakukan pengujian hipotesis, pengujian asumsi klasik tersebut melalui :

\section{Gambar 1 Uji Asumsi Klasik}

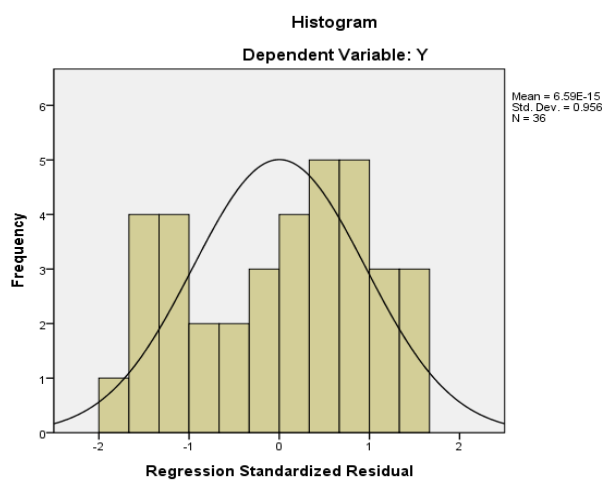

Sumber: Output SPSS 2015

Berdasarkan gambar menunjukkan bahwa grafik beta saham mengikuti distribusi normal dengan bentuk histogram yang hampir sama dengan bentuk distribusi normal, hal ini berarti bahwa data residual terdistribusi secara normal. 


\section{Gambar 2 Uji Asumsi Klasik}

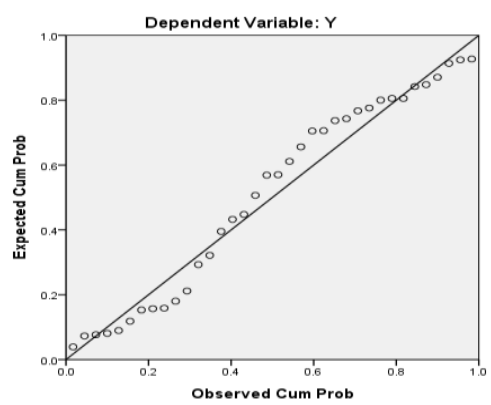

Sumber: Output SPSS 2015

Berdasarkan gambar diatas dapat disimpulkan bahwa pada garfik normal plot terlihat titik - titik yang menyebar disekitar garis diagonal, maka hal ini menunjukan bahwa model regresi tersebut berdistribusi normal artinya model regresi layak dipakai karena memenuhi asumsi normalitas.

\section{Uji Multikolinearitas}

\section{Tabel 2}

Uji Multikolinearitas

\begin{tabular}{|c|c|c|}
\hline \multirow{2}{*}{ Model } & \multicolumn{2}{|c|}{ Collinearity Statistics } \\
\cline { 2 - 3 } & Tolerance & VIF \\
\hline DPR & .790 & 1.265 \\
\hline FL & .778 & 1.286 \\
\hline ROA & .918 & 1.090 \\
\hline
\end{tabular}

Sumber: Output SPSS 2015

Berdasarkan tabel maka tolerance value $>0,1$ dan VIF $<10$, sehingga dapat disimpulkan bahwa ketiga variabel independen tersebut tidak terdapat hubungan multikolinearitas dan dapat digunakan untuk memprediksi kebijakan hutang selama periode pengamatan.

\section{Uji Heterokedastisitas}

\section{Gambar 3 Heterokedastisitas}

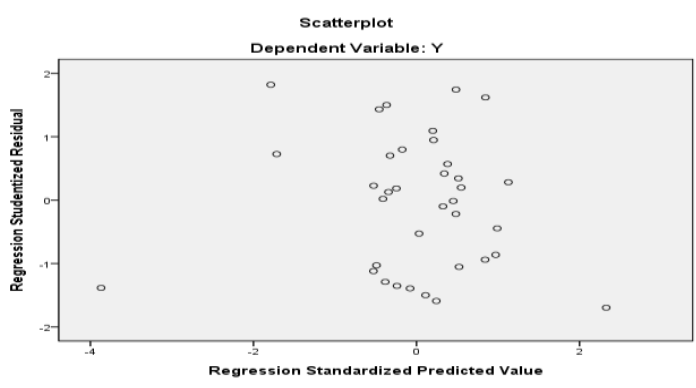

Sumber: Output SPSS 2015

Melalui grafik scatter plot pada gambar diatas dapat dilihat hasil uji heterokedastisitas menunjukkan bahwa model regresi tidak mengalami gangguan heterokedastisitas. Hal ini dapat terlihat dimana titik-titik tersebar tanpa membentuk suatu pola tertentu dan tersebar baik dibawah atau diatas angka 0 pada sumbu $Y$.

\section{Uji Autokorelasi}

Tabel 3

Uji Autokorelasi

\begin{tabular}{|l|r|}
\hline Model & Durbin-Watson \\
\hline 1 & 2.165 \\
\hline
\end{tabular}

a. Predictors:

(Constant), DPR, FL, ROA

b. Dependent Variable:

$\beta$

\section{Sumber: Output SPSS 2015}

Berdasarkan hasil uji autokorelasi didapat angka sebesar 2,087 berarti berada diantara 1,54-2,4. Menurut tabel rentang nilai Durbin-Watson maka apabila berada diantara 1,54 - 2,4 tidak menolak Ho, berarti tidak ada autokorelasi. Dengan demikian penelitian ini terbebas dari masalah autokorelasi. 


\section{Analisis Regresi Berganda}

Coefficients $^{\mathrm{a}}$

Tabel 4 Analisis Regresi Berganda

\begin{tabular}{|c|c|c|c|c|c|c|c|}
\hline \multirow[t]{2}{*}{ Model } & \multicolumn{2}{|c|}{$\begin{array}{c}\text { Unstandardized } \\
\text { Coefficients }\end{array}$} & \multirow{2}{*}{$\begin{array}{c}\text { Standardized } \\
\text { Coefficients } \\
\text { Beta }\end{array}$} & \multirow[t]{2}{*}{$\mathrm{T}$} & \multirow[t]{2}{*}{ Sig. } & \multicolumn{2}{|c|}{$\begin{array}{l}\text { Collinearity } \\
\text { Statistics }\end{array}$} \\
\hline & B & $\begin{array}{l}\text { Std. } \\
\text { Error }\end{array}$ & & & & Tolerance & VIF \\
\hline (Constant) & -.349 & .101 & & -3.444 & .002 & & \\
\hline DPR & -.016 & .009 & -.488 & -1.787 & .083 & .790 & 1.265 \\
\hline $\mathrm{FL}$ & 2.540 & .530 & .708 & 4.794 & .000 & .778 & 1.286 \\
\hline ROA & .064 & .013 & .855 & 5.019 & .000 & .918 & 1.090 \\
\hline
\end{tabular}

a. Dependent Variable: $Y$

Sumber: Output SPSS 2015

Berdasarkan hasil pada tabel diatas, dapat diketahui nilai konstan dan koefisien regresi sehingga dapat disusun persamaan regresi berganda linear sebagai berikut :

$Y=-0,349-0,016 X_{1}+2,540 X_{2}+0,64 X_{3}$

Berdasarkan regresi linear diatas, dapat penulis interpretasikan koefisien regresi dari masing-masing variabel independen sebagai berikut : konstanta yang dihasilkan sebesar $-0,349$, nilai koefisien regresi variabel DPR adalah 0,016 , nilai koefisien regresi variabel $\mathrm{FL}$ adalah 2,540, dan nilai koefisien regresi untuk variabel ROA adalah 0,64. Artinya setiap penambahan 1 masing-masing $X$ maka akan menaikkan variabel beta saham sebesar nilai koefisien masingmasing $X$.

\section{Uji Signifikan Parameter Individual (Uji Statistik t)}

Berdasarkan tabel diatas, pengujian hipotesis dalam penelitian ini dapat dijabarkan sebagai berikut :

1. DPR memiliki nilai $\mathrm{t}$ hitung $<\mathrm{t}$ tabel dan signifikansi $0,083>0,05$ yang artinya variabel dividen payout ratio tidak berpengaruh terhadap beta saham.

2. $F L$ memiliki nilai $t$ hitung $>t$ tabel dan signifikansi $0,00<0,05$ yang artinya variabel financial leverage berpengaruh secara signifikan terhadap beta saham.

3. $\mathrm{ROA}$ memiliki $\mathrm{t}$ hitung $>t$ tabel dan signifikansi $0,00<0,05$ yang artinya variabel return on assets berpengaruh signifikan terhadap beta saham.

\section{Uji Signifikansi Simultan (Uji Statistik F)}

Tabel 5 Uji Signifikansi Similan Uji-F ANOVA $^{a}$

\begin{tabular}{|l|l|l|l|l|l|}
\hline Model & $\begin{array}{l}\text { Sum of } \\
\text { Square } \\
\text { s }\end{array}$ & $\begin{array}{l}\text { Mean } \\
\text { Squar } \\
\text { e }\end{array}$ & F & Sig. \\
\hline $\begin{array}{l}\text { Regressio } \\
\mathrm{n}\end{array}$ & 17.488 & 3 & 5.829 & $\begin{array}{l}155.71 \\
5\end{array}$ & .000 \\
1Residual & 1.198 & 3 & .037 & & \\
Total & 18.686 & 3 & & & \\
\hline
\end{tabular}

a. Dependent Variable: $Y$

b. Predictors: (Constant), X3, X2, X1

Sumber : Output SPSS 2015 (data diolah)

Berdasarkan tabel diatas, menunjukkan bahwa hasil uji pada tabel ANOVA diperoleh pengaruh yang signifikan dilihat dari nilai signifikansi sebesar $0,00^{\mathrm{b}}<0,05$. Oleh karena itu dapat dikatakan bahwa ketiga variabel 
independen secara bersama-sama berpengaruh signifikan terhadap beta saham.

\section{Koefisien Determinasi $\left(\mathbf{R}^{2}\right)$}

Tabel 6 Koefisien Determinasi $\left(R^{2}\right)$

Model Summary ${ }^{b}$

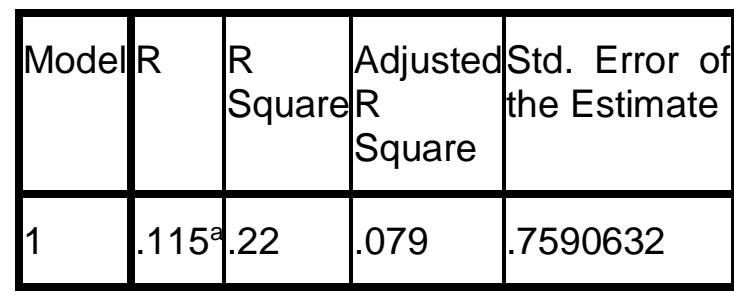

a. Predictors: (Constant), DPR, FL, ROA

b. Dependent Variable: Beta saham

Sumber: Output SPSS 2015 (data diolah)

Hasil perhitungan diatas menunjukan nilai koefisien determinasi yang dilihat dari nilai $R$ Square sebesar 0,22 yang berarti variabel kebijakan hutang mampu dijelaskan oleh variabel kepemilikan institusional, struktur aset, dan kebijakan dividen sebesar 0,22 atau $22 \%$ sedangkan selebihnya yaitu $78 \%$ dijelaskan oleh faktor lain yang tidak diteliti dalam penelitian ini.

\section{Pembahasan}

\section{Pengaruh Dividen Payout Ratio Terhadap Beta Saham}

Pada pengembangan hipotesis pertama telah disebutkan bahwa dividen payout ratio tidak berpengaruh terhadap beta saham dengan nilai $t_{\text {hitung }}<t_{\text {tabel, }}$ yaitu $-1,787<1,69092$.

Hasil ini sejalan dengan penelitian yang dilakukan oleh Dewi Nurcahyati (2013) mengatakan tidak dapat pengaruh yang signifikan antara dividen payout ratio terhadap beta saham. Namun hasil ini berbeda dengan hasil penelitian sebelumnya yang dilakukan oleh Reni Hardianti (2013) yang mengatakan terdapat pengaruh positif yang signifikan antara dividen payout ratio terhadap beta saham. Sedangkan pada hasil penelitian yang dikemukakan oleh Siti Umayah (2012) mengatakan bahwa terdapat pengaruh negatif yang signifikan antara dividen payout ratio terhadap beta saham. Pengujian terhadap dividen payout ratio tidak berhasil menyimpulkan hipotesis pertama yang berarti dividen payout ratio tidak berpengaruh terhadap beta saham. Hasil ini menunjukkan bahwa dividen yang telah dibagikan perusahaan kepada pemegang saham tidak akan berpengaruh lagi terhadap perusahaan.

\section{Pengaruh Financial Leverage Terhadap Beta Saham}

Hasil pengembangan hipotesis kedua menunjukkan bahwa financial leverage berpengaruh positif signifikan terhadap beta saham pada level $(0,00<$ $0,05)$, dengan nilai $t_{\text {hitung }}>t_{\text {tabel, }}$ yaitu 4,794 $>1,69092$.

Hasil ini selaras dengan penelitian Yulius Yulianto (2010) dan Agung Budi Prakosa (2012) yang menunjukkan bahwa financial leverage berpengaruh positif signifikan terhadap beta saham. Pengujian terhadap financial leverage gagal menyimpulkan hipotesis kedua yang berarti financial leverage berpengaruh positif signifikan terhadap beta saham. Hal ini disebabkan oleh saham yang telah terjual ke pasar modal tidak mempunyai pengaruh terhadap financial leverage perusahaan.

\section{Pengaruh Profitabilitas Terhadap Beta Saham}

Pada pengembangan hipotesis
ketiga telah disebutkan bahwa profitabilitas berpengaruh positif signifikan terhadap beta saham pada level $(0,00<$ $0,05)$ dengan nilai $t_{\text {hitung }}>t_{\text {tabel, }}$ yaitu 5,019 $>1,69092$.

Hasil ini sejalan dengan penelitian yang dilakukan oleh Maris Akfalia (2011), Nailatun Ni'mah (2013), dan Reni Hardianti (2013) konsisten yang menunjukkan bahwa adanya pengaruh profitabilitas terhadap beta saham. Pengujian terhadap profitabilitas berhasil menyimpulkan hipotesis ketiga yang berarti profitabilitas berpengaruh signifikan positif terhadap beta saham syariah. Hasil penelitian ini sesuai dengan teori yang menyebutkan bahwa return on assets adalah rasio yang mengukur kemampuan perusahaan dalam menghasilkan laba. 
Laba atau keuntungan yang dicapai perusahaan memberikan nilai positif bagi perusahaan, dan akan meningkatkan risiko perusahaan (Jogiyanto, 2003:130)

\section{Pengaruh Dividen Payout Ratio, Financial Leverage Dan Profitabilitas Terhadap Beta Saham}

Dari hasil uji $F$ diatas dapat disimpulkan bahwa dividen payout ratio $\left(\mathrm{X}_{1}\right)$, financial leverage $\left(\mathrm{X}_{2}\right)$ dan profitabilitas $\left(X_{3}\right)$ secara simultan berpengaruh signifikan terhadap beta saham syariah $(\mathrm{Y})$, hal ini dibuktikan nilai $F_{\text {hitung }}$ yang diperoleh sebesar 115,715 sedangkan nilai $\mathrm{F}$ tabel sebesar 2,90 pada level a $5 \%(0.00<0.05)$. Hal ini sejalan dengan penelitian yang dilakukan oleh Nur Kasanah (2013) dan Yulius Yulianto (2010) yang menyatakan bahwa variabelvariabel independen di atas secara simultan berpengaruh signifikan terhadap beta saham.

\section{KESIMPULAN}

Berdasarkan hasil penelitian yang dilakukan maka dapat ditarik kesimpulan sebagai berikut :

Dividen payout ratio tidak berpengaruh signifikan terhadap beta saham, hal tersebut dilihat dari pengembangan hipotesis dengan nilai $t$ hitung $<\mathrm{t}$ tabel, yaitu $-1,787<1,69092$. Dividen payout ratio adalah perbandingan antara dividen yang dibagikan dengan laba bersih yang diperoleh. Hasil penelitian ini menunjukan bahwa tinggi rendahnya dividen payout ratio tidak mempengaruhi beta saham syariah.

Financial leverage berpengaruh signifikan positif terhadap beta saham syariah, hal tersebut dilihat dari hasil pengembangan hipotesis yang memperoleh tingkat signifikan sebesar $(0,00<0,05)$, dengan nilai $\mathrm{t}$ hitung $>\mathrm{t}$ tabel, yaitu 4,794 > 1,69092. Hasil penelitian ini menunjukkan bahwa saham yang telah terjual ke pasar modal tidak mempunyai pengaruh terhadap financial leverage perusahaan.

Profitabilitas berpengaruh signifikan positif terhadap beta saham, hal tersebut dilihat dari hasil pengembangan hipotesis yang memperoleh tingkat signifikan sebesar $(0,00<0,05)$, dengan nilai $t_{\text {hitung }}$ $>\mathrm{t}$ tabel, yaitu 5,019 > 1,69092. Hasil ini menunjukkan profitabilitas yang meningkat akan memberikan nilai positif bagi perusahaan, sehingga mengurangi risiko perusahaan, dan akan meningkatkan beta atau risiko perusahaan, karena keuntungan atau return menurut (Jogiyanto, 2003:130) mempunyai hubungan yang positif dengan risiko.

Secara simultan dividen payout ratio, financial leverage, dan profitabilitas berpengaruh signifikan terhadap beta saham syariah, hal tersebut dilihat dari hasil pengujian hipotesis yang memperoleh tingkat signifikan sebesar $(0.000<0.05)$.

\section{IMPLIKASI KETERBATASAN}

DAN

Berdasarkan penelitian yang telah dilakukan, Penelitian selanjutnya diharapkan mampu memberikan hasil penelitian yang lebih berkualitas dengan mempertimbangkan saran berikut :

Bagi emiten diharapkan dapat meminimalisir risiko saham di perusahaan agar investor tertarik menginvestasikan dananya di perusahaan.

Praktisi dan investor pasar modal diharapkan mempertimbangkan keputusan dalam berinvestasi. Dari hasil penelitian diharapkan investor mampu memprediksi risiko saham dan menilai kinerja suatu perusahaan.

\section{DAFTAR PUSTAKA}

\section{Buku}

Atmaja, Lukas Setia. 2008. Teori dan Praktik Manajemen Keuangan. Penerbit CV.ANDI OFFSET. Yogyakarta.

Fakhruddin, Hendy. M. 2008. Tanya Jawab Pasar Modal. PT Elex Media Komputindo Kelompok KompasGramedia. Jakarta. 
Ghozali, Imam. 2012. Aplikasi Analisis Multivariate Dengan Program IBM SPSS 21 Edisi 7. Badan Penerbit Universitas Diponegoro. Semarang.

Hamzah, Ardi.2005. Perbandingan Beta Saham Syariah Dan Beta Saham Non Syariah Dalam Analisa Ekonomi Makro, Industri Dan Karakteristik Perusahaan. Simposium Riset Ekonomi II. Surabaya.

Hanafi, Mamduh M, Halim Abdul. 2009. Analisis Laporan Keuangan. UPP STIM YKPN. Yogyakarta.

Harahap, Sofyan Safri. 2008. Analisis Kritis atas Laporan Keuangan. Raja Grafindo Persada. Jakarta.

Hartono, Jogiyanto. 2003. Teori Portofolio dan Analisa Investasi. BPFE. Yogyakarta.

Hartono, Jogiyanto. 2007. Teori Portofolio dan Analisis Investasi. BPFE. Yogyakarta.

Hartono, Jogiyanto. 2008. Teori Portofolio dan Analisis Investasi. BPFE. Yogyakarta.

Hartono, Jogiyanto. 2010. Teori Portofolio dan Analisis Investasi. Edisi Keenam. BPFE. Yogyakarta.

Husnan, Suad. 1998. Manajemen Keuangan : Teori dan Penerapan Buku II, Edisi 4. BPFE. Yogyakarta.

Husnan, Suad. 2001. Dasar-Dasar Teori Portofolio dan Analisis Sekuritas. YKPN. Yogyakarta.

Husnan, Suad. 2005. Dasar-Dasar Teori Portofolio \& Analisis Sekuritas. UPP STIM YKPN. Yogyakarta.

Irawati, Susan. 2006. Manajemen Keuangan. PUSTAKA. Bandung.

Kustini, Sri. 2011. Pengaruh Dividen Payout Ratio, Return On Asset Dan Earning Variability Terhadap Beta Saham Syariah. Jurnal. Universitas Negeri Semarang.
Lestari, Wuryaningsih. Dwi. 2013. Kriteria January Effect yang Meliputi Harga Saham, Volume Perdagangan Saham, dan Return Saham pada Saham Jakarta Islamic Index (JII) Periode 2007-2012. Skripsi. Universitas Sunan Kalijaga Yogyakarta.

Muhammad. 2005. Pengantar Akuntansi Syariah. Salemba Empat. Jakarta.

Riyanto, Bambang. 2001. Dasar-dasar Pembelanjaan Perusahaan, edisi 4. BPFE- Yogyakarta.

Sartono, Agus. 2010. Manajemen Keuangan Teori dan Aplikasi. BPFE. Yogyakarta.

Sawir, Agnes. 2000. "Analisis Kinerja Keuangan \& Perencanaan Keuangan Perusahaan", Cetakan Kedua. PT. Gramedia Pustaka Utama. Jakarta.

Sudarsono, Heri. 2007. Bank dan Lembaga Keuangan Syariah. Ekonisa. Yogyakarta.

Sugiyono. 2014. Metode Penelitian Kuantitatif, Kualitatif dan $R \quad \& \quad D$. ALFABETA, CV. Bandung.

\section{Website}

http://m.beritametro.co.id/ekonomi/beidorong-edukasi-pasar-modal-tanpa-batas www.sahamok.com

www.idx.co.id www.google.com 